\title{
ROLA KOLEKTORÓW W ROZPROWADZANIU SUBSKRYPCJI PIŚMIENNICTWA NAUKOWEGO W PIERWSZEJ POŁOWIE XIX WIEKU
}

Badania nad prenumeratą jako jedną z form sprzedaży piśmiennictwa naukowego wymagają także rozpoznania mechanizmów jej funkcjonowania. Uruchomienie różnych kanałów, przy pomocy których przekazywano informacje o prenumeracie, niewątpliwie było jednym z czynników decydujących o powodzeniu akcji wydawniczej, liczebności nabywców wydanej książki, a w konsekwencji wpływało również na zasięg i strukturę publiczności czytelniczej.

Prezentowany szkic ma na celu ukazanie dróg rozpowszechniania prenumeraty, a przede wszystkim wyjaśnienie roli osób prywatnych zwanych kolektorami w podejmowanych akcjach wydawniczych. Przedstawione wnioski pochodzą z badań nad prenumeratą i prenumeratorami piśmiennictwa naukowego wydanego na ziemiach Królestwa Polskiego w latach 1800-1863.

$W$ interesującej nas epoce subskrypcja należała do jednego $z$ często stosowanych sposobów wydawania publikacji o treści naukowej. Często wobec braku środków finansowych autorzy rozmaitych rozpraw dążyli do zebrania funduszy w drodze przedpłaty, ogłaszając tym samym prenumeratę. Także wydawcy-księgarze chętnie wcześniej poszukiwali nabywców, zapewnizło to bowiem bezpieczny zbyt określonej liczby egzemplarzy.

W każdym przypadku organizatorzy subskrypcji starali się o pozyskanie możliwie największej liczby osób nabywających bilety prenumeracyjne. Podejmowanym działaniom towarzyszyła możliwie szeroka popularyzacja planowanego przedsięwzięcia. Działania informacyjne prowadzono w dwojaki sposób - wykorzystując prasę oraz poprzez pośrednictwo osób prywatnych - kolektorów. Potencjalnie prasa stanowiła, z uwagi na zasięg, najbardziej efektywny środek przekazu, przy czym szczególna rola przypadała gazetom codziennym jako pismom o najszerszym społecznym odbiorze ${ }^{1}$. Na łamach dzienników warszawskich, np.: „Kuriera Warszawskiego", „Gazety Codziennej" pojawiały się liczne ogłoszenia o subskrypcjach oraz wiadomości o realizacji poszczególnych przedsięwzięć wydawniczych. W przypadku interesującego nas piśmiennictwa istotne znaczenie jako źródło informacji o prenumeracie miały także czasopisma naukowe i fachowe. Adresowane były one do środowisk o określonych zainteresowaniach, tam też upatrywano odbiorców określonych książek. Wspomniane zjawisko jest dobrze widoczne w przypadku funkcjonowania piśmiennictwa medycznego i farmaceutycznego. Wydawany w Warszawie „Pamiętnik Lekarski” stanowił istotne źródło informacji o 
nowych publikacjach. Podobnie liczne ogłoszenia o prenumeracie książek znajdujemy na łamach periodyków o tematyce rolniczej, rolniczo-technicznej i prawniczej.

Ogłoszenia prasowe o subskrypcji zawierały krótką informację o autorze i jego dziele oraz dane o stronie edytorskiej książki i cenie. Jako miejsce zbierania zgłoszeń wymieniano księgarnie, stacje pocztowe, niekiedy redakcje czasopism, rzadziej inne ośrodki. Niemalże zawsze wymieniano także osoby prywatne trudniące się zbieraniem prenumeraty.

Jak wspomniano, wykorzystywano również księgarnie, upatrując w nich dogodne miejsce zbierania przedpłaty. Anonse prasowe wskazują, iż księgarnie należały do stałych punktów przyjmowania prenumeraty i tylko nieliczni autorzy rezygnowali z ich pośrednictwa. Do stałych punktów zbierania zgłoszeń należały znane oficyny warszawskie. Dbano również o pozyskanie nabywców wśród mieszkańców ziem wschodnich, przyjmując przedpłatę w księgarniach wileńskich, pojedynczo w Krzemieńcu i Żytomierzu. Wydawcy upatrywali również odbiorców w Krakowie, Lwowie i Poznańskiem, gdzie miejscowe księgarnie przyjmowały prenumeratę na wydawnictwa warszawskie. W poszczególnych przypadkach zasięg geograficzny prenumeraty układał się rozmaicie, w zależności od tematyki dzieła i inwencji wydawców. W każdym jednak przypadku omawiany sposób pozyskiwania nabywców ograniczony był zasięgiem i strukturą sieci księgarskiej.

Do innych ośrodków zbierania subskrypcji na prowincji należały urzędy i stacje pocztowe. W latach 1800-1830 za ich pośrednictwem rozsyłano przede wszystkim gazety i czasopisma. W latach międzypowstaniowych pośrednictwo poczty staje się pomocne w przesylaniu wydawnictw wielotomowych, poszytowych ukazujących się sukcesywnie. Rozprowadzanie publikacji za pośrednictwem poczty wiązało się $z$ dodatkowymi opłatami ponoszonymi przez czytelnika, niekiedy też zdarzaly się przypadki niesumiennego realizowania przesyłki $i^{2}$.

Ogłoszenia o prenumeracie, o czym wspomniano, często wymieniały nazwiska osób prywatnych trudniących się sprzedażą biletów subskrypcyjnych i rozprowadzających wydrukowane już egzemplarze. Obok księgarzy i poczty pomoc kolektorów w pozyskiwaniu prenumeratorów okazywała się niezbędna przez całe sześćdziesięciolecie. Z pośrednictwa poczty i księgarni często korzystały osoby o określonych motywacjach czytelniczych, kolektorzy zaś niejednokrotnie pozyskiwali nabywców wśród osób o niesprecyzowanych zainteresowaniach, przekonując ich o konieczności uczestniczenia w prenumeracie.

Listy prenumeratorów zazwyczaj nie wskazują kolektorów. Dowiadujemy się o nich z ogłoszeń prasowych, notatek w prasie informujących o przebiegu prenumeraty lub z podziękowań autorskich, wyrażających wdzięczność za pomoc w sprzedaży wydanego dzieła. Julian Ursyn Niemcewicz wydawszy „Dzieje panowania Zygmunta III" wymieniał szereg znakomitych dam, „(..) które podjąć się raczyły sprzedaży biletów jako to: JW. ordynatowa Zamoyska, hrabina Waleria Tarnowska, generałowa Węgorzewska, JW. Jakubowa Wodzicka, JW. z Przyłuskich Sulistrowska, księżna JW. Lubomirska"3. Szczególną pomoc autorowi okazał ówczesny gubernator Wołynia sprzedający bilety prenumeracyjne na prowincji, poszerzając tym samym znacznie grono nabywców o miejscowych ziemian. 
Pomoc kolektorów okazywała się także przydatna w organizowaniu prenumeraty literatury fachowej, adresowanej do określonych kręgów. Anons o subskrypcji rozprawy „Rzecz o sądownictwie najwyższym” Damazego Dzierożyńskiego powiadamiał, iż prenumerata „Przyjmuje się u Brzeziny przy ulicy Miodowej w Warszawie oraz raczyli podjąć się takowej W. Dawid Torosiewicz, W. Józef Owidzki mecenasi przy sądzie najwyższym Królestwa Polskiego, W. Chobrzyński patron w Płocku, W. Łojewski patron w Kaliszu”. . Podobnie w przypadku wydawania "Geometrii analitycznej” Adriana Krzyżanowskiego, poza księgarniami, prenumeraty „(...) następujące osoby podjąć się raczyły (...): profesor Kassyas w Poznaniu, profesor Dziekoński w Kaliszu, X. Polejowski rektor szkoły wojewódzkiej w Lublinie"5.

Podobnie w 1861 r. wydawcy pism Józefa Żochowskiego, zawiadamiając o miejscach zbierania prenumeraty wymieniali, obok księgarń warszawskich i redakcji „Gazety Warszawskiej”, Mieczysława Żochowskiego, studenta uniwersytetu w Kijowie ${ }^{6}$.

Funkcji kolektora podejmowały się osoby zaprzyjaźnione $z$ autorem lub wydawcą, często też korzystano z protekcji osób znanych i poważanych w określonych środowiskach, gdyż ich pomoc zapewniała pozyskanie większej liczby nabywców. Wackaw Aleksander Maciejowski wydawszy drugą edycję dzieła z historii prawa rzymskiego, upraszał Joachima Lelewela o pomoc, pisząc do niego: „Do wydania jego obrałem drogę prenumeraty; bądź łaskaw sprzedać mi 40 biletów i przywieźć do Warszawy pieniądze"7. Podobnie Jan Sowiński, autor „Uczonych Polek", dziękując Lelewelowi za rozdanie biletów, prosił o dodatkową pomoc i wsparcie. „Gdyby nie dobroć jego nieśmiałbym posłać jeszcze 25 biletów, których część W. Józef Korzeniowski chętnie przyjmie na siebie" - pisał w liście ${ }^{8}$. W niektórych przypadkach, zwłaszcza przy większej liczbie biletów powierzonych kolektorowi, starał się on o pomoc osób zaprzyjaźnionych, docierając $w$ ten sposób do dalszych kręgów nabywców. Józef Jaroszewicz, profesor prawa w Krzemieńcu, na prośbę Lelewela rozprowadzający bilety w swoim mieście, donosił: „Jużem rozprzedał wszystkie prenumeraty na dzieło W. Maciejowskiego, prenumeratorów nazwiska dołączam"'.

Pomoc osób prywatnych okazywała się przydatna także w przypadku subskrypcji ogłaszanych w okresie międzypowstaniowym. Kazimierz Władysław Wójcicki zwracal się w liście do Józefa l. Kraszewskiego o pomoc w sprzedaży prenumeraty „Cmentarza Powązkowskiego", pisząc: „Nasze prowincje prawie nie znają «Powązek», prenumeratorów przynajmniej nie mialem żadnych. Pomyśl kochany Panie Józefie, czy sam lub za pośrednictwem pewnych osób, nie dało się zbyć kilkadziesiąt egzemplarzy"10.

Prowadzone badania wskazują na istotną rolę kolektorów w rozprowadzaniu prenumeraty, szczególnie z uwagi na ich aktywność w pozyskiwaniu nabywców poszczególnych książek. Nieformalne więzi społeczne, kontakty towarzyskie często stanowily ważny czynnik decydujący o uczestniczeniu w prenumeracie. Pomoc kolektorska okazywała się szczególnie przydatna na prowincji, gdzie działalność miejscowych księgarn bywała niewystarczająca, a podrażające koszty pośrednictwa poczty zniechęcało potencjalnych nabywców. Zachęta kolektora w tym przypadku była szczególnie ważna. Zjawisko to nabiera tym większego znaczenia, iż 
niemalże połowa prenumeratorów piśmiennictwa naukowego wydanego w Warszawie pochodziła z prowincji Królestwa Polskiego i po części z ziem pozostałych zaborów.

Działalność kolektorów nie zawsze przebiegała bezkolizyjnie, o czym świadczą głosy uskarżające się na niesumienność wspomnianych osób. Tomasz Massalski, wydający poezje brata, donosił Lelewelowi z Wilna: „(...) dzięki Bogu doprowadziłem do końca to przedsięwzięcie, chociaż z kolektorami mam wielki kłopot, egzemplarze prenumeratorom pooddawać należało, a pieniędzy większa połowa zalega na kolektorach"11. Niekiedy wydawcy byli zmuszeni napominać na łamach prasy, „(...) aby osoby, które raczyły zajać się zbieraniem przedpłaty, imienną listę prenumeratorów na toż dzieło najdalej na dzień 10 czerwca nadesła$\mathrm{hy}^{\prime \prime 2}$. Niezależnie od wspomnianych trudności wydawcy, dążąc do rozszerzenia grupy nabywców, zachęcali do zakupu większej liczby książek zapewniając, iż zbierający dziesięciu prenumeratorów otrzyma jedenasty egzemplarz bezpłatnie ${ }^{13}$.

Odszukanie wszystkich osób trudniących się zbieraniem subskrypcji na podstawie sporządzanych imiennych list prenumeratorów jest niemożliwe. Pewną wskazówkę stanowi nabywanie większej ilości egzemplarzy, aczkolwiek mógł to być po prostu przejaw mecenatu ze strony zamożniejszych prenumeratorów. O protektorach „Słownika języka polskiego" pisał Samuel B. Linde, sporządzając imienny wykaz osób, „(...) które nadzwyczajnym wsparciem dzieło to łaskawie zaszczyciły". W ich gronie znalazł się cesarz rosyjski, król pruski, Adam Czartoryski, ordynat Zamoyski, biskup wileński Kossakowski i Aleksander Pociej. Podobnie Niemcewicz wspominał swoich protektorów, wspomagających go $w$ sprzedaży biletów prenumeracyjnych, jak i wyrażał wdzięczność wobec Rozalii Rzewuskiej, która „(...) najpiękniejszymi rycinami w Wiedniu trudnić się raczyła" ${ }^{14}$. Z reguly jednak szczególne wsparcie udawało się pozyskać w przypadku dzieł o prestiżowym znaczeniu. W pozostałych przypadkach, wobec braku mecenatu państwowego i pomocy możnych protektorów istotna stawała się aktywność samych prenumeratorów, którzy poprzez zakup większej liczby egzemplarzy ułatwiali autorowi i wydawcy uzyskanie zwrotu poniesionych nakładów. W przypadku nabycia kilku egzemplarzy możemy domniemywać, jak wspomniano, iż przeznaczano je dla osób postronnych.

Na podstawie informacji o ilości zakupionych egzemplarzy, spośród niemalże trzydziestu tysięcy prenumeratorów piśmiennictwa naukowego, udało się wyróżnić niewielką grupę nabywającą co najmniej trzy egzemplarze. Liczy ona 349 osób, przy czym dziesięć i więcej egzemplarzy nabyło 102 prenumeratorów, zaś trzy do pięciu egzemplarzy zakupiło 195 subskrybentów. Wśród tego rodzaju nabywców znajdują się przedstawiciele różnych grup społecznych. Najliczniejszą grupę stanowi inteligencja, przede wszystkim urzędnicy, uczeni i prawnicy, pojedynczo lekarze, literaci i inżynierowie. W miarę jednak nabywania większej liczby egzemplarzy (powyżej dziesięciu), liczba przedstawicieli inteligencji spada z 35\% do $31 \%$. Podobną tendencję obserwujemy w przypadku duchowieństwa, liczniej pojawiajacego się w grupie osób nabywających mniej niż dziesięć egzemplarzy $(4,4 \%-$ $1,9 \%)$ oraz wśród kupców i bankierów (15\% - 11\%). Odwrotną sytuację dostrzegamy w przypadku udziału ziemiaństwa, relatywnie wyższego w grupie nabywajacej powyżej dziesięciu egzemplarzy $(24 \%-29 \%)$. Aktywni także okazują się wysocy urzędnicy, stanowiący odpowiednio $7,2 \%$ i $12 \%$. 
Jednocześnie należy zwrócić uwagę na stosunkowo znaczny udział dostojników państwowych oraz kupców i bankierów w omawianej grupie, przewyższający ich uczestnictwo w całkowitym zbiorowisku prenumeratorów. Wysocy urzędnicy zakupili większą ilość „Słownika rosyjsko-polskiego" Antoniego Jakubowicza, ich zainteresowanie wzbudzity także „Zasady ekonomii” Ludwika Jacoba oraz „Mechanika i geometria sztuk i rzemiosł" Karola Dupina. W pewnych przypadkach omawiane zjawisko możemy łączyć ze wspieraniem akcji wydawniczych cieszących się poparciem i akceptacją ze strony rządu (np.: „Słownik” Jakubowicza). Natomiast tak znaczna aktywność sfer bankiersko-kupieckich łączy się przede wszystkim z prenumeratą „Fedona” Mojżesza Mendelsshona, którego po piętnaście egzemplarzy nabyli $\mathrm{m}$.in. Simon i Mathias Rosen. Przedstawiciele tej grupy sporadycznie zaś uczestniczą w innych akcjach wydawniczych, jak np. Leopold Kronenberg zakupujący dla siebie i rodziny dziesięć egzemplarzy rozprawy Michała Gliszczyńskiego "Hus i Husyci".

Zaprezentowane w szkicu rozważania upoważniają nas do sformułowania kilku wniosków. Badania wskazują przede wszystkim na ważną rolę osób prywatnych w rozprowadzaniu prenumeraty wszelkiego piśmiennictwa naukowego i popularnego niezależnie od tematyki publikacji. Osoby prywatne trudniące się sprzedażą biletów subskrypcyjnych funkcjonowały we wszystkich środowiskach, z których rekrutowali się prenumeratorzy, tj. głównie wśród inteligencji i ziemiaństwa. Ta pozainstytucjonalna forma pozyskiwania nabywców, wykorzystując kontakty towarzyskie, wiązała się z możliwością bezpośredniej reklamy książki, wręcz - można powiedzieć - namowy do jej nabycia. Niemałe znaczenie w tej sytuacji odgrywała także osoba kolektora, którego prośbie niejednokrotnie nie chciano bądź nie umiano odmówić. Występowanie u części prenumeratorów nie tylko czytelniczych motywacji w konsekwencji umożliwizło zebranie dostatecznej ilości nabywców, co pozwalało na pomyślne zakończenie akcji wydawniczej. O skuteczności prowadzonych działań świadczy fakt, iż tylko niewielka część podejmowanych subskrypcji zakończyła się niepowodzeniem z braku odbiorców. Wydaje się, iż działania osób prywatnych były niezbędne w pomyślnym funkcjonowaniu prenumeraty, niezależnie od pośrednictwa księgarń i poczty. Zjawisko to jest dobrze widoczne szczególnie na prowincji, gdzie sieć księgarska niejednokrotnie okazywała się niewystarczająca, zaś z pośrednictwa poczty korzystała tylko nieliczna część czytelników. Należy też wspomnieć, iż zarówno poczta, jak i po części księgarnia nie posiadały tak znacznych możliwości oddziaływań, jak działo się to w przypadku kolektorów.

Zaprezentowane sugestie badawcze wymagają jeszcze dalszych dociekań. Dokładniejszych ustaleń wymaga z pewnością problem sporządzenia kompletnego wykazu kolektorów. Prowadzone badania warto też rozszerzyć o wyjaśnienie roli, jaką odgrywali kolektorzy w przypadku funkcjonowania prenumeraty piśmiennictwa beletrystycznego.

\section{Przypisy}

${ }^{1}$ Zasięg publiczności czytelniczej pism ogólnoinformacyjnych wydanych w latach 1815-1830 szacowano na 30-40 tysięcy osób. W następnym trzydziestoleciu zasięg prasy uległ rozszerzeniu. Por. Z. Anculewicz, Rozwój prenumerat gazet i czasopism w Królestwie Polskim w latach 1815-1864. „Kwartalnik Historii Prasy Polskiej", T. 26:1 987, z. 4, s. 5-21. 
2 M. Czernik, Poczta Królestwa Polskiego w latach 1815-1851. Organizacja i dokumentacja działalności, Wroclaw 1987, s. 222-228.

3 J.U. Niemcewicz, Dzieje panowania Zygmunta III, t. 1, Warszawa 1819, Wstęp.

4 "Themis Polska czyli pismo nauce i praktyce prawa poświęcone", T. 1:1828, s. 277-278.

5 "Kurier Warszawski" 1822, nr 282, s. 3.

${ }^{6}$ Tamże, 1861 , nr 73, s. 348.

${ }^{7}$ List W.A. Maciejowskiego (b. daty). Korespondencja do Joachima Lelewela. Biblioteka Jagiellońska, rps sygn. 4435, t. 3, k. 510.

${ }^{8}$ List J. Sowińskiego z 14 VI 1820. Tamże, t. 5, k. 703.

${ }^{9}$ List J. Jaroszewicza z 28 III 1824. Tamże, t. 2, k. 65-66.

${ }^{10}$ List do J.I. Kraszewskiego z 14 | 1858. Korespondencja J.I. Kraszewskiego 1844-1863. Biblioteka Jagielloríska rps sygn. 6481, seria 3, t. 23, k. 277.

${ }^{11}$ List T. Massalskiego z 6 | 1829. Korespondencja do J. Lelewela..., t. 3, k. 626.

12 „Gazeta Codzienna” 1840, nr 2839, s. 1. Ogłoszenie dotyczyło prenumeraty „Zasad botaniki i fizjologii" S. Pisulewskiego.

${ }^{13}$ Np.: ogłoszenie w „Kurierze Warszawskim" 1841, nr 2, s. 5 zawierające zapowiedź wydania „Pism ulotnych" M. Rubinsteina.

14 J.U. Niemcewicz, op. cit., Wstęp. 